exchanges. By its efforts and interest in producing a vigorous program of self-regulation with governmental aid in the over-the-counter industry the Commission has shown that it considers the unorganized markets as important in their special capacity as are the exchanges in that portion of the securities business which they serve. The Maloney Act offers a splendid chance for the whole over-the-counter business to create a vigorous self-regulatory scheme under which it can proceed ${ }^{116}$ not only to terminate exchange encroachments upon trading which would normally go over-the-counter but also to obtain for itself a maximum amount of all the securities business which for one reason or another is not peculiarly suited to exchange trading.

\title{
SUSPENSION OF CORPORATE CHARTER FOR NONPAYMENT OF FRANCHISE TAX
}

All STATES have statutes requiring that domestic corporations pay franchise fees and file annual reports. Many of these acts provide in addition that noncompliance calls for suspension or forfeiture of the corporate charter. ${ }^{1}$ Though varied in form, these laws have in common the double objective of securing revenue for the state and exercising control over corporate

116. In a speech before the Investment Bankers' Association, Henry H. Egly, Chief of the Securities Association Division of the S. E. C., suggested the following outline for the program to be carried out by the proposed registered associations:

"1. Financial responsibility which includes such aspects as (a) Kecping and preservation of books and records; (b) Filing of financial statements: (1) Nature thereof; (2) Treatment; (c) Inspection of books and records; (d) Establishment of some ratio between dealer's indebtedness and capital; (e) The question of margin transaction by brokers and dealers for own account; (f) Filing of information in respect to current underwriting commitments and net positions; (g) Reporting of loans partly or wholly unsecured.

2. Safeguarding the funds and securities of customers. (a) Hypothecation of sccurities carried for customers' accounts. (b) Commingling of customers' funds.

3. Safeguards against unreasonable profits and commissions.

4. The problem of manipulation and proper provisions for stabilization.

5. Quotations. (a) Adequacy and public dissemination. (b) Fictitious quotations.

(c) Nominal quotations.

6. Regulation of market letters, brokers' circulars and other advertising.

7. Salesmen. Qualifications, training, supervision and compensation.

8. Discretionary accounts. (a) Management by broker. (b) Management by dealer.

9. Participation by association in enforcement of commission rules.

10. Technique of trading, deliveries, settlements, etc."

S. E. C. Release (December 7, 1938).

1. See e.g., Cal. Gen. Laws (Deering, 1937) Act 8488, \$32; Mich. Comp. Laws (Mason, Supp. 1933) §10135-87; Tex. Ann. Stat. (Vernon, 1925) art. 7091, 7092. 
affairs. The problems which their interpretation and enforcement raise, never academic, are intensified during periods of economic stress.? 1 hen drastic retrenchment is necessitated, payment of the franchise tax is ostensibly easily dispensable, not one of the immediate requirements of a going business. Especially to less sizable corporations does the lery loom large in proportion to total disbursements. ${ }^{3}$ In many cases an organization fighting for survival may have little choice but to fail to remit the tax. If such corporations, or others which have inadvertently omitted payment of the levy, continue to do business, or, having ceased active operation, attempt to resume activities upon the return of more prosperous times, complex and vital questions arise as to rights and liabilities during suspension and upon reinstatement. $^{\overline{ }}$ Cases interpreting the various statutes present a startling patchwork quilt of logic, yet it is possible to discern certain basic assumptions and predilections running through the decisions. This comment attempts to collect and correlate the varied rulings, and to isolate the principles which have motivated courts in their determinations.

The first predisposition, perhaps the most important in terms of the results eventually attained, is self-evident. Here, as elsewhere, forfeitures are not favorites of the law. ${ }^{6}$ The effect of this idea upon the flexible, directive terminology employed by the varied statutes in fixing the penalty for violation has been to produce uniformity of interpretation. Whether the statute speaks in terms of "forfeiture," "dissolution,"8 or "suspension," the majority of courts hold that there is at most but a suspension of the corporate powers. ${ }^{10}$ Even where the opinion talks in terms of forfeiture, the results

2. In Michigan in two years (1931-32) over 3000 corporations forfeited their charters for nonpayment of the franchise tax. By 1936 the number had dropped to 975. Swearingen, Corporations Whose Charters Haz'i Become roid (1937) 16 IfICr. S. B. J. 149. In New York, 250,000 corporations have been stricken from the corporation indes: since 1929. N. Y. Times, Dec. 16, 1938, p. 39, col. 5.

3. The taxes are rarely a flat rate on the franchise, but not infrequently the seale of gradation is such that the small corporation is penslized. See (1937) 16 MIrce. S. B. J. 580.

4. This evidently occurred in San Leandro Canning Co. v. Perillo, 84 Cal. App. 627, $258 \mathrm{Pac} .666$ (1927) and Mirphy v. Wheatley, 102 AId. 501, 63 Atl. 62 (1905). For an instance of refusal to pay because of dispute over the amount, see Turner v. Western Hydro-Electric Co., 241 Xfich. 6, 216 N. W. 476 (1927).

5. See generally, Swearingen, loc. cit. supra note 2; (1937) 16 Mfrcr. S. B. J. 580.

6. Enunciations of this policy are legion. See e.g., Briggs v. Cape Cod Canal Co., 137 Mass. 71, 72 (1884); Galveston Ry. v. State, 81 Tex. 572, 596 (1591); 6 Cook, Corporations (8th ed. 1923) $\$ 637 ; 16$ Fletcher, Corporatrons (Perm. ed. 1933) $\$ 8035$; 2 Kent's CoMMrentaries (13th ed. 1884) 306.

7. Tex. Anv. Stat. (Vernon, 1925) art. 7091.

8. ORE. CODE ANN. (1930) \$25-250.

9. CAI. GEN. LAws (Deering, 1937) Act $8488, \$ 32$.

10. Mathews v. Life Ins. Co. of Detroit, 279 N. W. 858 (Mich. 1938); Deschutes Co. v. Lara, 127 Ore. 57, 270 Pac. 913 (1928); Real Estate-Land Title \& Trust Co. v. Dildy, 92 S. IW. (2d) 318 (Tex. Civ. App. 1936). For the minority view see Young Construction Co. v. Dunne, 123 Kan. 176, 254 Pac. 323 (1927). 
are often those of suspension. ${ }^{11}$ Reluctant to hold that failure to comply with certain stipulated conditions could ipso facto forfeit the charter, courts have consistently maintained that a forfeiture may only be declared in proceedings instituted for that purpose by the state. ${ }^{12}$ The legislative pawer to provide for spontaneous forfeiture is generally conceded.13 Yet in the more unusual instances in which the statutory language is apparently conclusive of automatic forfeiture, it has nevertheless been declared that whether the facts exist which warrant the application of the provision is a question for judicial determination. ${ }^{14}$ Until the state acts in quo warranto, the corporate charter may be merely suspended. ${ }^{15}$ The right of revivor which numerous statutes grant upon the payment of back taxes and certain fines has often been the straw seized upon as conclusive of a legislative intent not to work absolute forfeiture. ${ }^{16}$ As a final indication of the disinclination to impose this drastic penalty, the courts, lending the otherwise plastic language a hard, unyielding side, exact the strictest compliance by the state with the statutory provisions before the forfeiture can be made effective. ${ }^{17}$

A second basic assumption of a majority of courts is that the familiar analogy drawn between corporate existence and that of an individual is, in this situation, no longer adequate; it is obvious that the suspended corporation is neither "alive" nor "dead" in the familiar judicial meaning of these

11. Klamath Lumber Co. v. Bamber, 74 Ore. 287, 145 Pac. 650 (1915). When precise terminology is not required, courts often use forfeiture and suspension interchangeably.

12. Cluthe v. Railway, 176 Ind. 162, 95 N. E. 543 (1911); State $c . x$ rel. City Council v. Railroad, 51 S. C. 129,28 S. E. 145 (1897) ; Greenbrier Lumber Co. v. Ward, 30 W. Va. 43,3 S. E. 227 (1887).

13. See Brooklyn Steam Transit Co. v. Brooklyn, 78 N. Y. 524, 529 (1879); State ex rel. City Council v. Railroad, 51 S. C. 129, 132, 28 S. E. 145, 146 (1897); Young Cont struction Co. v. Dunne, 123 Kan. 176, 180, 254 Pac. 323, 325 (1927). But see Reichert v. Ellis Ferry Co., 184 Ky. 150, 154, 211 S. W. 403, 405 (1919).

14. In Frosts' Lessee v. Frostburg Coal Co., 24 How. 278 (U. S. 1860) the Supreme Court held a statute not to be self-executing even though it read "the corporate powers and privileges shall cease and determine." And in Atchafalaya Bank v. Dawson, 13 La. 497 (1839) recourse to the courts was held necessary though the statute read: ". . . the charter shall be ipso facto forfeited and void . . ." For a complete collection of the cases, see 16 Fletcher, Corporations (Perm. ed. 1933) \$7988.

15. At least one state treats the nonpayment of the tax as a cause of forfeiture which the state may enforce, with a suspension of the charter until the forfeiture has been judicially determined. Federal Crude Oil Co. v. Yount-Lee Oil Co., 122 Tex. 21 , 52 S. W. (2d) 56 (1932) ; Bunn v. Laredo, 213 S. W. 320 (Tex. Civ. App. 1919); (1933) 11 TEx. L. Rev. 250.

16. Bokel v. Zitnik, 93 Colo. 565, 27 P. (2d) 753 (1933); State $e x$. rel. Bowen v. Superior Court, 135 Wash. 315, 237 Pac. 722 (1925).

17. Ferguson Fruit \& Land Co. v. Goodding, 44 Idaho 76, 258 Pac. 557 (1927); Woodward Hardware Co. v. Fisher, 269 Mo. 271, 190 S. W. 576 (1916); Deschutes Co. v. Lara, 127 Ore. 57, 270 Pac. 913 (1928). See also Elliott's Coal Co. v. State Corp. Comm., 123 Va. 63, 96 S. E. 353 (1918) (forfeiture refused for failure to notify corporation that its tax was due) and Weil v. Richardson, 224 Mo. App. 990, 24 S. W. (2d) 175 (1930) (suspension refused because of incorrect entry by Secretary of State). 
terms. The fact that the corporate charter is to some intents void and yet the corporation can be reinstated has necessitated a new terminology. Courts have, as a result, talked in terms of "suspended animation."18 This hybrid concept, a sort of myopic forfeiture, is a stranger to orthodox legal doctrine, but, as will be demonstrated later, it has permitted the attainment of desirable results in certain situations.

\section{Liabilities of Suspended Corporation}

Creditors' Rights: Since a corporation which has omitted payment of franchise taxes is almost always in precarious financial circumstances, the rights of its creditors, if suspension does occur, become a paramount issue. Early decisions compared the expiration or forfeiture of the corporate charter to the death of an individual. ${ }^{19}$ All actions by ${ }^{20}$ and against ${ }^{21}$ the corporation were thought to cease immediately. A judgment obtained after "death" against such a corporation could be collaterally attacked.: The extinction was complete and instantaneous unless there was a statutory provision to the contrary. ${ }^{23}$ To alleviate the inequities engendered by this rule, legislatures long ago enacted statutes the general purport of which was to make the directors of a dissolved corporation trustees of the corporate rights, powers, and property. They were vested with authority to wind up affairs and distribute assets of the organization. ${ }^{24}$ Some states provided for a continuation of the corporation itself for a limited period, but only for the

18. Comm'r of Internal Revenue v. Bryson, 79 F. (2d) 397 (C. C. A. 9th, 1935); Held v. Crosthwaite, 260 Fed. 613 (C. C. A. 2d, 1919); Ransome-Crummey Co. v. Superior Ct., 188 Cal. 393, 205 Pac. 446 (1922).

See also Swearingen, supra note 2, at 152. The author points out that the suspended corporation is without power to exercise its normal functions, yet since it is not dissolved, it exists in the eyes of the law.

19. In Greely v. Smith, 10 Fed. Cas. No. 574 , at 1075 (C. C. D. Me. 1845) Mir. Justice Story said: "I cannot distinguish between the case of a corporation and the case of a private person dying pendente lite . . . and therefore any suit pending against it at its [the corporation's] death abates by mere operation of the law." Quoted with approval in National Bank v. Colby, 21 Wall. 609 (U. S. 1874). See also Lyon-Gray Lumber Co. v. Life Ins. Co., 247 S. W. 652 (Tex. Civ. App. 1923).

20. Oklahoma Natural Gas Co. v. Oklahoma, 273 U. S. 257 (1927); Ameriean Transportation Co. v. Swift \& Co., 22 F. (2d) 457 (S. D. N. Y. 1927); Young Construction Co. v. Dunne, 123 Kan. 176, 254 Pac. 323 (1927).

21. Sinnott v. Hanan, 214 N. Y. 454, 108 N. E. 858 (1915); Shepherd v. Kress Box Co., 154 Va. 421,153 S. E. 649 (1930); Hawley v. Bonanza Queen Co., 61 Wash. 90, 111 Pac. 1073 (1910).

22. Garrett v. Pilgrim Mines Co., 47 Idaho 595, 277 Pac. 567 (1929).

23. Oklahoma Natural Gas Co. v. Oklahoma, 273 U. S. 257 (1927); Lyon Gray Realty Co. v. Life Ins. Co., 269 S. W. 80 (Tex. Comm. App. 1025).

24. See e.g., Conn. GeN. Stat. (1930) \$3471. For interpretation of similar statutes, see Pease v. Rathbun Jones Co., 243 U. S. 273 (1917); Mretropolitan Rubber Co. v. Place, 147 Fed. 90 (C. C. A. 2d, 1906); Stiles v. Laurel Fork Oil \& Coal Co.n 47 W. Va. 838,35 S. E. 986 (1900). 
purpose of winding up its affairs, and not for the transaction of any new business. ${ }^{25}$ The end was identical in both instances.

A few statutes, which in reality provicle for forfeiture even though a right of revivor is extended and which, contrary to the general tendency previously indicated, have been so construed, ${ }^{26}$ vest either in the directors as trustees, ${ }^{27}$ or directly in the corporation, ${ }^{28}$ the power to terminate the business. In such cases, the powers and liabilities of the corporation become identical with those arising upon dissolution, and have received wide attention under that head. ${ }^{29}$ Similarly, if the statute expressly permits suits against the suspended corporation, ${ }^{30}$ few questions arise. ${ }^{31}$ But if, as ustully happens, no provision is made for preserving rights of action, the problem presents difficulties and has elicited various responses. There is often invoked a new assumption-that suspension is a penalty imposed by the state for noncompliance with a revenue or regulatory measure. ${ }^{32}$ Sentient courts thus conclude that since the penalty is intended to be operative solely against the corporation, the law should not serve as its protector by abating creditor's actions then pending or preventing the latter from instituting stuit. Since the corporation is in a state of legal though somnolent existence during suspension, it is not to be relieved of just debts which accrued prior to that time. ${ }^{33}$ Under this rule a judgment would not be subject to collateral attack

25. Typical is DeL. Rev. Code (1935) \$2074. See Pomeroy's Lessee v. State Bank, 1 Wall. 23 (U. S. 1863) ; Nome \& Sinook Co. v. Ames Mercantile Co., 187 Fcd. 928 (C. C. A. 9th, 1911) ; Hasselman v. Japanese Co., 2 Ind. App. 180, 28 N. E. 207 (1891).

26. American Surety Co. v. Great White Spirit Co., 58 N. J. Eq. 526, 43 Atl. 579 (1899); Package Sales Corp. v. Cincinnati Orchards Co., 24 Ohio N. P. (N.s.) 313 (Munic. Ct. 1922).

27. Gardiner v. Automatic Arms Co., 275 Fed. 697 (N. D. N. Y. 1921) ; Norton v. Steinfeld, 36 Ariz. 536, 288 Pac. 3 (1930); Four-S Razor Co. v. Guymon, 110 Kan. 745, 205 Pac. 635 (1922).

28. Tradesmen's Nat. Bank v. Johnson, 54 F. (2d) 367 (D. Md. 1931); Division Ave. Realty Co. v. McGough, 274 Mich. 163, 264 N. W. 328 (1936); Deschutes Co. v. Lara, 127 Ore. 57, 270 Pac. 913 (1928).

29. For general discussion of the effect of dissolution on pending suits, see 16 Fletcher, Corporations (Perm. ed. 1933) $\$ \S 8147,8148$.

30. See e.g., Cal. Gen. Laws (Deering, 1937) Act 8488 , §32, Nelson v. Marsh, 100 Cal. App. 578, 280 Pac. 695 (1929).

31. The corporation is, of course, given the right to defend, but may obtain only defensive relief. Notice would be served as though the corporation were not suspended. California Bean Growers Ass'n v. Lewellyn Bean Co., 228 Mich. 489, 200 N. W. 162 (1924) ; Mathews v. Life Ins. Co. of Detroit, 279 N. W. 858 (Mich. 1938).

32. The statutes are universally viewed by the courts as being penal in nature. Sec e.g., Indian Protective Ass'n v. Gordon, 34 App. D. C. 553 (1910), aff'd, 225 U. S. 698 (1911); Klamath Lumber Co. v. Bamber, 74 Ore. 287, 145 Pac. 650 (1915); Deveny v. Success Co., 228 S. W. 295 (Tex. Civ. App. 1921).

33. State ex rel. Bowen v. Superior Ct., 135 Wash. 315, 237 Pac. 722 (1925) ; Finch v. Finch, 68 Cal. App. 72, 228 Pac. 553 (1924). Decisions under this proposition include not only money judgments [Nathan v. American Photoplayer Co., 95 Cal. App. 320, 272 Pac. 775 (1928); Nelson v. Marsh, 100 Cal. App. 578, 280 Pac. 695 (1929) ], but 
on the grounds of non-existence of the corporate body when it was obtained $^{34}$ Further, since under this theory the corporation still possesses a modified existence as an entity, suit could be maintained only against the corporation and not against the stockholders or directors as trustees. ${ }^{35}$ It is doubtful, moreover, if any jurisdiction would permit a recovery against the corporation for damages caused directly by the suspension of business in obedience to the statute unless payment was withheld with the express purpose of escaping contractual obligations. A minority of courts cut adrift from the general current of authority and construe the vague terms of the typical statute to mean that actual forfeiture is intended. ${ }^{30}$ Actions pending against the corporation are abated, and no new suit may be instituted. ${ }^{37}$ Even in the absence of statute, a federal court has indicated that directors or stockholders may then be sued, ${ }^{38}$ but not all state courts have followed this lead. Needless to say, if suspension statutes are to be regarded as regulatory measures, the better rule appears to be to permit actions directly against the corporation in order that suspension will not penalize creditors.

Different, but none the less difficult problems arise when a suspended corporation continues to do business and liabilities arise after, as opposed to before, the date of suspension. The continuation may be in wilful violation of the law, ${ }^{39}$ or in ignorance of the fact that suspension has actually occurred. ${ }^{40}$ Such a corporation has been held to be neither de jure nor de facto, as there has been no colorable attempt to comply with the law. Hence acts done by it are null and void, and no recovery may be had against it.41 The question of recourse in this situation against stockholders or directors is apparently one of good faith. The general reluctance to hold directors or stockholders liable as co-partners where they have no linowledge of the

foreclosure actions as well. Hazard v. Park, 294 Fed. 40 (C. C. A. Sth, 1923) ; Eversman v. Ray Shipman Co., 115 Ohio St. 269, 152 N. E. 643 (1926); W'est Parl Realty Co. v. Porth, 192 Wis. 307, 212 N. W. 651 (1927). Contra: Young Construction Co. v. Dunne, 123 Kan. 176, 254 Pac. 323 (1927).

34. Ohio Nat. Bank v. Construction Co., 17 App. D. C. 524 (1901) ; Farmer's State Bank v. Brown, 52 N. D. 806, 204 N. W. 673 (1925); IVest Park Realty Co. v. Porth, 192 Wis. 307,212 N. W. 651 (1927).

35. Nathan v. American Photoplayer Co., 95 Cal. App. 320, 272 Pac. 775 (1923); Southern Land Co. v. Paulk, 99 Cal. App. 775, 279 Pac. 496 (1929); Usher v. Henkel, 205 Cal. 413, 271 Pac. 494 (1928).

36. This may be a reaction to legislative criticism of the general reluctance to permit automatic forfeiture. Courts following this interpretation differ as to whether the state dissolution statutes may then apply.

37. Hawley v. Bonanza Queen Co., 61 Wash. 90, 111 Pac. 1073 (1910).

38. Gardiner v. Automatic Arms Co., 275 Fed. 697 (N. D. N. Y. 1921).

39. Bergeron v. Belisle, 256 Mich. 225, 239 N. IV. 277 (1931); Jones v. Young, 115 W. Va. 225, 174 S. E. 885 (1934).

40. See note 4, stipra.

41. Finch v. Finch, 68 Cal. App. 72, 228 Pac. 553 (1924); Paclage Sales Corp. v. Cincinnati Orchards Co., 24 Ohio N. P. (N.s.) 313 (Munic. Ct. 1922). 
actual state of affairs ${ }^{42}$ has been extended to suspension cases. ${ }^{43}$ Where, however, officers have continued the corporate business with knowledge of the suspension, no such reluctance has been evinced. ${ }^{44}$ Thus where a stum of money was given a corporation in return for a note and stock of the company and the corporation had been suspended at the time of the transaction, the directors as individuals were held liable on the nate. ${ }^{45}$ Similarly, where a corporation after suspension of its charter continued in business by agreement of its stockholders, the latter were held individually liable in a tort action instituted by an injured employee. ${ }^{46}$ This distinction seems hardly to be open to criticism.

The supposedly somniferous corporation is viewed in a few jurisdictions as having a de facto existence if it continues to carry on its business without interruption and to undertake obligations in disregard of the order of stuspension. ${ }^{47}$ Under this interpretation the corporation may be sted as such and is liable for all acts committed before or during the suspension period.48 A contract to repurchase treasury stock has been held enforceable against a suspended corporation even though the agreement was consummated after suspension occurred. ${ }^{49}$

The relative merits of the contrasting views are difficult to resolve. A judgment against a corporation which has no assets is worthless, and studies indicate that a substantial proportion of suspended corporations find themselves in that unfortunate position. ${ }^{50}$ Yet it could be argued that a creditor

42. Commercial Nat. Bank v. Gilinsky, 142 Iowa 178, 120 N. W. 476 (1909); Central City Bank v. Walker, 66 N. Y. 424 (1876). See Dodd, Parthcrship Liability of Stockholders in Defective Corporations (1927) 40 HARv. L. Rev. 521.

43. Owensboro Wagon Co. v. Bliss, 132 Ala. 253, 31 So. 81 (1901). Thus an innocent stockholder has been held not liable as a co-partner on a note executed in the name of the corporation after the charter had become void. Adams v. First Nat. Bank, 294 S. W. 909 (Tex. Civ. App. 1927).

44. Baker v. Bates-Street Shirt Co., 6 F. (2d) 854 (C. C. A. 1st, 1925) ; Nat. Union Bank v. Landon, 45 N. Y. 410 (1871) ; Jones v. Young, 115 W. Va. 225, 174 S. E. 885 (1934). See generally 1 Machen, Corporations (1st ed. 1908) $\$ 293$; (1926) 14 Calm. L. Rev. 486; (1922) 7 MrNn. L. Rev. 42.

45. Silvey v. Fink, 99 Cal. App. 528, 279 Pac. 202 (1929). The court held that since during suspension the directors were without power to borrow money for the corporation, execute its note, or enter into a contract for the sale of stock, the note and subscription agreement were void and plaintiff never became owner of the stock.

46. Jones v. Young, 115 W. Va. 225, 174 S. E. 885 (1934); (1934) 41 W. VA. L. Q. 81 .

47. Held v. Crosthwaite, 260 Fed. 613 (C. C. A. 2d, 1919); (1919) 28 YALE L. J. 604. See generally Carpenter, De Facto Corporations (1912) 25 HaRv. L. Rev. 623; Warren, Collateral Attack on Incorporation-A. De Facto Corporations (1907) 20 HArv. L. Rev. 456; Comment (1936) 84 U. of PA. L. Rev. 514.

48. Bergeron v. Belisle, 256 Mich. 225, 239 N. W. 277 (1931); Sun River Co. v. Montana Bank, 81 Mont. 222, 262 Pac. 1039 (1927); Goldstein v. Mitchell, 14 Ohio App. 231 (1921) (contract concluded after suspension); Deschutes Co. v. Lara. 127 Ore. 57, 270 Pac. 913 (1928).

49. Fites v. Marsh, 171 Cal. 487, 153 Pac. 926 (1915).

50. See Swearingen, loc. cit. stupra note 2. 
who dealt with a corporation as such should be at his peril to determine the legal existence of the organization and estopped from recourse against directors or stockholders. ${ }^{51}$ The former argument is perhaps the stronger. There seems to be no compelling reason why recourse should not be permitted against officials who have knowingly continued corporate activity in violation of law. Civil liability would penalize them as individuals; the state in proper proceedings could punish the corporation itself. 52

Stockholders' Rights: The relation of the suspended corporation to its stockholders has been adjudicated in but few aspects. But the underlying assumptions are ostensibly the same as in the case of suits by creditors. It has been held that since the state is primarily concerned with regulation and revenue, ${ }^{53}$ any stockholder might revive the corporation by payment of the franchise tax and penalties. ${ }^{54}$ Suit by him on behalf of, ${ }^{55}$ or directly against the corporation ${ }^{56}$ might then follow. But stockholders' rights are limited by those of the corporation. Hence in jurisdictions where the suspended corporation can not maintain suit, stockholders are likewise precluded when the corporation is the real party in interest. ${ }^{5 \pi}$ Where a solvent corporation failed to pay its tax in order to effect a fraudulent purpose, a minority stockholder has been denied the right to use the non-payment as an indication of insolvency and sue for the appointment of a receiver. ${ }^{58}$ On the other hand, courts have been commendably liberal in permitting stockholders' suits against the directors for an accounting after non-payment of the tax. ${ }^{.09}$ In general, the stockholders of a suspended corporation may maintain an action if its purpose is to prevent or correct fraud." 0

Rights of the State: Whether the state may, upon revivor, assess the tax for the period during which the corporation has been suspended has never

51. It has been held that a party dealing with a suspended corporation as a corporation will be estopped from denying its existence at the time the transaction occurred. Ferguson Fruit and Land Co. v. Goodding, 44 Idaho 76, 253 Pac. 557 (1927); Ohio Nat. Bank v. Construction Co., 17 App. D. C. 524 (1901).

52. See Eversman v. Ray Shipman Co., 115 Ohio St. 269, 277, 152 N. E. 643, 645 (1926) ; Adams v. First Nat. Bank, 294 S. W. 909 (Tex. Civ. App. 1927).

53. See note 32, supra.

54. Usher v. Henkel, 205 Cal. 413, 271 Pac. 494 (1928); Southern Land Co. Y. McKenna, 100 Cal. App. 152, 280 Pac. 144 (1929).

55. Southern Land Co. v. ArcKenna, 100 Cal. App. 152, 280 Pac. 144 (1929).

56. Usher v. Henkel, $205 \mathrm{Cal}$. 413, $271 \mathrm{Pac}$. 494 (1923). In those jurisdietions where the corporation may be sued even though suspended, this mode of procedure would of course be superfluous.

57. A judgment obtained in such a manner may be collaterally attacked. Smith v. Lewis, 211 Cal. 294, 295 Pac. 37 (1930).

58. Reade v. Broadway Theatre Co., 99 N. J. Eq. 282, 132 Atl. 477 (Ch. 1926).

59. Estel v. Midgard Inv. Co., 46 S. W. (2d) 193 (Mo. App. 1932). It has bsen held that in a suit to compel an accounting, the corporation is an indispensable party. Watts v. Vanderbilt, $45 \mathrm{~F}$. (2d) 968 (C. C. A. 2d, 1930). One can only sraculate as to the effect of this decision in those jurisdictions in which the corporation cannot be sued.

60. Gardiner v. Automatic Arms Co., 275 Fed. 697 (N. D. N. Y. 1921). 
been adjudicated. In an analogous but not identical situation-the imposition of a franchise tax during bankruptcy or receivership-courts are hopelessly divided. ${ }^{61}$ The cases diverge along two entirely irreconcilable theories. One group holds that the tax is on the right to "be", and as the corporation at the time of assessment is practically if not actually dissolved, there can be no taxable franchise. ${ }^{62}$ The other maintains that the tax is on the right to "do," i.e., upon the exercise of the franchise and not upon the franchise itself. Thus if the receiver or trustee continues the ordinary business of the corporation, the tax may be assessed. ${ }^{63}$ A recent Supreme Court decision, limited to extremely narrow grounds, did not completely dispel the for that obscures the rulings. ${ }^{64}$ The court held that the federal courts were bound to follow the state interpretation, which in that particular instance held that the tax was on the exercise of the privilege conferred by the sovereign. ${ }^{05}$ An intimation by the late Mr. Justice Cardozo that this was a preferable interpretation may, however, serve as an admonition to state as well as ferleral courts that the tax should be on the right to "do." 60 Neither of the above principles would seem to apply directly in suspension cases, as theoretically the corporation can not act and in legal contemplation it exists only for certain purposes, such as exercising the right of revivor. Thus it is neither "being" nor "doing," and logically no tax should be imposed cluring the period of suspension. Even if the corporation does continue its ordinary business, it is believed that the state's remedy should lie rather in enforcing the suspension statute and exacting appropriate penalties by direct proceedings. ${ }^{07}$

61. The cases are collected in (1922) 18 A. L. R. 700.

62. Ohio v. Harris, 229 Fed. 892 (C. C. A. 6th, 1916), cert. dcnicd, 242 U. S. 034 (1916) ; Johnson v. Johnson Bros., 108 Me. 272, 80 Atl. 741 (1911). For the contrary view that the franchise is not legally terminated and the privilege of exercising the franchise remains, even though practically useless, and that hence the tax is assessable, see In re Malko Milling \& Lighting Co., 32 F. (2d) 825 (D. Md. 1929) ; State v. Bradley, 207 Ala. 677, 93 So. 595 (1922).

63. Bright v. Arkansas, 249 Fed. 950 (C. C. A. 8th, 1918) ; In re Detroit Properties Corp., 254 Mich. 523, 236 N. W. 850 (1931). Conversely, when the recoiver cloes not carry on the corporate business, the tax may not be imposed. Greenfield Savings Bank v. Commonwealth, 211 Mass. 207, 97 N. E. 927 (1912).

64. Michigan v. Michigan Trust Co., 286 U. S. 334 (1932). See Comment (1932) 30 Mich. L. Rev. 1094; (1932) 41 Yale L. J. 471; (1932) 30 Mich. L. Rev. 1346.

65. The rule was enunciated in $I n$ rc Detroit Properties Co., 254 Mich. 523, 236 N. W. 850 (1931). But it was disregarded by the Circuit Court of Appeals. Michigan Trust Co. v. Michigan, 52 F. (2d) 842 (C. C. A. 6th, 1931).

66. Thompson v. Louisiana, 98 F. (2d) 108 (C. C. A. 8th, 1938), and Lowden v. State Corporation Commission, 76 P. (2d) 1139 (N. Mex. 1938), are indicative that this warning may not go unheeded.

67. See cases cited supra note 52. It could be argued that one purpose of the monetary penalties was to replace the revenue lost through nonpayment of the tax duriug the suspension period. 


\section{Rights of the CoRporatiox}

Privilege of Maintaining Suit: Statutes regulating the rights of the corporation and limiting corporate activities during suspension are sparse in detail. Typical are those laws which simply provide, without further elaboration, that the corporate powers are terminated until revived by the fulfillment of specified conditions. The important question of the right of the corporation to sue in its own name for affirmative relief then becomes purely one of judicial interpretation. The answers are varied. One jurisdiction has indicated that the legislature may not constitutionally prohibit access to the courts on a cause of action arising before suspension. ${ }^{6 R}$ The same theory, with a slightly different shading, underlies the ruling that a suspended corporation may not be denied admission to the courts when the suit is incident to winding up the business. ${ }^{69}$ The rationale of this decision apparently is that the provision for forfeiture is absolute, but that its penal or regulatory nature must not dény to any organization the privileges incident to ordinary dissolution proceedings. And there is, of course, a wide latitude in determining what winding up the business may entail. Suits have been entertained under this theory for the eviction of trespassers from land acquired before suspension, ${ }^{70}$ to collect rents, ${ }^{71}$ and to enforce the ubligations of promissory notes. ${ }^{72}$

A third approach is illustrated by the ruling that a suit instituted by a suspended corporation had sufficient substance to permit the substitution of the directors as party-plaintiffs, ${ }^{73}$ even though the corporation itself was barred from court. This result was reached in apparent disregard of a statute which, though it permitted actions originated by corporate officials, expressly denied the privilege of suit to the corporation itself. Through use of the "suspended animation" concept the court endowed the corporation with a sort of diaphanous existence and arrived at a desirable result. Still a fourth set of decisions prohibits the maintenance of any suit. ${ }^{74}$ Jurisdictions adhering to this rule apparently view suspension as complete forfeiture

68. Stephens County v. AicCammon, 40 S. W. (2d) 67 (Tex. Comm. App. 1931). But cf. Federal Crude Oil Co. v. Yount-Lee Oil Co., 122 Tex. 21, 52 S. W. (2d) 56 (1932). That a suspended corporation may sue at any time sce State cx rel. Bowen v: Superior Ct., 135 Wash. 315, 237 Pac. 722 (1925).

69. McKee v. Standard Minerals Corp., 18 Del. Ch. 97, 156 Atl. 193 (1931); Ferguson Fruit \& Land Co. v. Goodding, 44 Idaho 76, 258 Pac. 557 (1927); cf. Four-S Razor Co. v. Guymon, 110 Kan. 745, 205 Pac. 635 (1922).

70. Federal Crude Oil Co. v. Yount-Lee Oil Co., 122 Tex. 21, 52 S. W. (2d) 55 (1932).

71. Division Ave. Realty Co. v. McGough, 274 Afich. 163, $26+$ N. II. 328 (1936).

72. Tradesmen's Nat. Bank \& Trust Co. v. Johnson, 54 F. (2d) 367 (D. Mrd. 1931).

73. Norton v. Steinfeld, 36 Ariz. 536, 288 Pac. 3 (1930); Weckes Grain \& Livestock Co. v. Ware \& Leland, 99 Neb. 126, 155 N. W. 233 (1915).

74. Garrett v. Pilgrim Mines Co., 47 Idaho 595, 277 Pac. 567 (1929); Havens \& Co. v. Apartment House Co., 97 Neb. 639, 150 N. W. 1011 (1915); Xceldman Cartage

Co. v. Fruehauf Trailer Co., 271 Mich. 304, 259 N. IV. 905 (1935). 
and all rights of action pending at the time suspension occurs are abated.75 Nor may directors bring or continue suit where the corporation is the real party in interest. ${ }^{76}$ A judgment obtained by either the corporation or its offcers is void and subject to collateral attack even after reinstatement has occurred. ${ }^{77}$

Through these varied decisions one unifying thread may perhaps be drawn. In general, if the cause of action arose before suspension or could be called incident to winding up the business, the suit will be allowed unless explicitly prohibited by statute. Conversely, if the cause of action arose during suspension or is not incident to winding up the affairs, suit is precluded. The unifying factor which permits this hesitant generalization is undoubtedly the concept previously outlined, that the primary purpose of suspension is to penalize the corporation for its default. Courts impose the maximum penalty which can be inflicted without denying to the corporation the essential privilege of dissolution.

Title Transfers and Assignments: The assumption that the corporation is in a state of "suspended animation" is plainly evident in cases dealing with transfers of titles and assignments. Perhaps here more than elsewhere is the peculiar concept used as a means of achieving equitable ends. A suspended corporation may serve as repository of title, ${ }^{78}$ and, however illogical it may appear upon a cursory inspection, a deed transferred by a suspended corporation, unless otherwise provided by statute, ${ }^{70}$ is valid. ${ }^{80}$ Mechanics liens and mortgages executed after suspension are prior liens even as against creditors' claims matured before cancellation of the corporate charter. ${ }^{\text {81 }}$ If, however, a statute vests title in the directors as trustees during suspension, then of course a conveyance by the corporation is void. ${ }^{82}$ Conversely, in those jurisdictions where title remains in the corporation, a purported conveyance by the directors is a nullity. ${ }^{83}$ The latter holding again illustrates

75. Young Construction Co. v. Dunne, 123 Kan. 176, 254 Pac. 323 (1927); KKlamath Lumber Co. v. Bamber, 74 Ore. 287, 145 Pac. 650 (1915); Hawley v. Bonanzat Queen Co., 61 Wash. 90, 111 Pac. 1073 (1910).

76. Gulf Coast Shrine Club v. Clarkson, 74 S. W. (2d) 1048 ('Tes. Civ. App. 1034). Nor may a receiver bring suit until revivor is effected. Young Construction Co. v. Dunne, 123 Kan. 176, 254 Pac. 323 (1927).

77. Smith v. Lewis, 211 Cal. 294, 295 Pac. 37 (1930).

78. Deschutes Co. v. Lara, 127 Ore. 57, 270 Pac. 913 (1928). This is dircctly opposed to the ruling in the case of dissolved corporations, which may not accept deeds or conveyances. Klorfine v. Cole, 121 Ore. 76, 254 Pac. 200 (1927).

79. Usher v. Henkel, 205 Cal. 413, 271 Pac. 494 (1928) (statute provided all acts during suspension were void).

S0. Landis Bros. Co. v. Lawrence, 107 Cal. App. 499, 286 Pac. 177 (1930) ; Ferguson Fruit and Land Co. v, Goodding, 44 Idaho 76, 258 Pac. 557 (1927).

81. Eversman v. Ray Shipman Co., 115 Ohio St. 269, 152 N. E. 643 (1926).

82. Weil v. Richardson, 224 Mo. App. 990, 24 S. W. (2d) 175 (1930).

83. Southern Land Co. v. Paulk, 99 Cal. App. 775, 279 Pac. 496 (1929); Sotthern Land Co. v.. McKenna, 100 Cal. App. 152, 280 Pac. 144 (1929); Bokel v. Zitnils, 93 Colo. 565, 27 P. (2d) 753 (1933). 
the suspended animation theme, since were it not for this helpful concept, the corporation itself would be powerless to act, but conveyance by the directors would be valid. ${ }^{84}$

A corporation may not defeat the penal purpose of a suspension statute or the restrictions imposed on it by assigning causes of action to third parties. $^{85}$ If it does so, in those jurisdictions which deny the suspented corporation admission to the courts, the assignee is also precluded from suit. ${ }^{g s}$ Similarly, a judgment received before suspension may not be assigned for execution if by statute all acts of the corporation during suspension are void. ${ }^{8 \pi}$ In some jurisdictions it might be possible to present a lugical argument that such execution was but an incident of winding up the lusiness, hence the judgment could either be executed by the corporation or assigned. ${ }^{39}$

Bankruptcy: The federal courts have repeatedly enunciated the pulicy that no state statute will be permitted to hamper or restrict the measure of protection afforded creditors by the Bankruptey Act. The death of an insulvent individual who has committed acts of bankruptcy priur to the filing of a bankruptcy petition defeats jurisdiction. ${ }^{50}$ But it has uniformly been declared that corporations dissolved by decree of a state tribunal in ano ciurranto proceedings are amenable to the Bankruptcy Act. ${ }^{30}$ Though the corpuration

84. This principle is further extended by permitting the suspenderl corporation to pay its taxes at any time. Even where statutes expressly deny the right to transact business during suspension, the corporation may redeen its property at a tax sale. Ruth v. Devany, 84 Colo. 476, 271 Pac. 623 (1928).

85. Bengel v. Kenney, 126 Cal. App. 735, 14 P. (2d) 1031 (1932).

86. Bengel v. Kenney, 126 Cal. App. 735, 14 P. (2d) 1031 (1932). Eccauce of the Full Faith and Credit Clause, a suspended corporation may not bring suit in a ioreign state eren though the suspension decree has not been entered in the state in which the action is brought. And as a suit by the corporation may not he entertained, an assignment of a cause of action is void and the assignee may not recover thereon in a suit in a foreign state. Siegal v. Maryland Casualty Co., 178 N. Y. Supp. 391 (Sup. Ct. 1919).

87. Panzer-Hamilton Co. v. Bray, 96 Cal. App. 460, 274 Pac. 769 (1929). But of. First Nat. Bank r. Little, 6 S. W. (2d) 819 (Tex. Civ. App. 19281.

S8. This argument apparently prevailed in Tradesmen's Nat. Banl: \& Trust Co. v. Johnson, $5+$ F. (2d) 367 (D. MId. 1931).

89. In re Fackelman, 248 Fed. 565 (S. D. Cal. 1918); Adams v. Terrell, 4 Fed. 705 (C. C. W. D. Tex. 1880). For complete discussion sce Lyon Realty Co. v. Mliburn Realty Co., 56 F. (2d) 187, 183 (D. 1Id. 1932).

90. In re 211 East Delaware Place Bldg. Corp., 70 F. (2d) 834 (C. C. A. 7th, 1935) ; Capitol Endowment Co. v. Kroeger, \&6 F. (2d) 976 (C. C. A. G4h, 1936); cf. Vassar Foundry Co. v. Whiting Corn., 2 F. (2d) 240 (C. C. A. Gth, 1924). Sce (1935) 35 CoL. L. Rev. 108; (1935) 45 HARv. L. Rev. 676; (1936) 22 V.A. L. Rev. 465. This result follows despite pleas in abatement or motions to quash filed on the gruunds that the corporation no longer existed and hence the court had nothing over which it could acquire jurisdiction. In re Adams \& Hoyt Co., 164 Fed. $4 \$ 9$ (N. D. Ga. 1908). In In re Booth's Drugstore, Inc., 19 F. Supp. 95 (IT. D. V3. 1937), the court held that a netition in bankruptcy could be maintained against the corporation for an act committed subsequent to the revocation of its charter. (1938) 44 W. VA. L. Q. 219. The fact that a receiver has been engaged for some time in winding up affairs of the corporation is immaterial to exercise of federal power. Austin v. Thomas, $78 \mathrm{~F}$. (2d) 602 (C. C. A. 6th, 1935), (1935) 20 MIARQ. L. REv. 42. 
is legally non-existent or "dead," it has a qualified existence for the purpose of being declared a bankrupt. It is not surprising to find courts even more willing to extend the bankruptcy privilege to corporations which are merely suspended, as this presents fewer logical hurdles than dissolution. ${ }^{\text {g1 }}$ The concept of qualified existence and the principle that suspension is not intended to destroy the rights of creditors are again available. ${ }^{22}$

In view of the virtual unanimity of the many decisions on this point, two recent cases require comment. In the first, a suspended corporation attempted to file under Section 75 of the Bankruptcy Act. It was held that since a suspended corporation was incapable of carrying on business, the principal part of the corporate income could not be derived from agriculture, hence the requisite factor for jurisdiction under Section 75 was lacking. ${ }^{03}$ The court was careful to dismiss the action without denying the corporation all rights under the Bankruptcy Act, but the case is indicative that difficulty may be encountered in qualifying for the rehabilitation sections of the Act. In the second case, the Supreme Court denied the right of a corporation to enter voluntary bankruptcy two years after dissolution for non-payment of a franchise tax, even though at the time of the petition the corporation was defending a suit in another court and could thus claim a qualified existence. ${ }^{.4}$ There was a vigorous dissent, and the decision was expressly limited to the precise issue, the court reserving the question as to the propriety of a petition by a creditor as opposed to the attempt at voluntary bankruptcy. Thie case is likely to be limited to the narrow issue decided. Even if it should be held to be controlling for dissolved corporations, it is extremely doubtful if the principle will be extended to corporations in a state of "suspended anima" tion." $"$ Nor does there seem to be any reason for denying to suspended corporations or their creditors the protection afforded by the Act. Kather has it been convincingly argued that the latter was intended to be given a broad inclusion. ${ }^{96}$

91. Old Fort Improvement Co. v. Lea, 89 F. (2d) 286 (C. C. A. 4 th, 1937) (lapse of 9 years since appointment of receiver and 18 months since suspension for non-payment of tax); In re Pacific Alloy \& Steel Co., 299 Fed. 952 (C. C. A. 9th, 1924); In rc Double Star Brick Co., 210 Fed. 980 (N. D. Cal. 1913).

92. It has also been argued that in bankruptcy proceedings the court talies hold of the res rather than the person of the bankrupt. In $r e$ Double Star Bricl: Co., 210 Fred. 980 (N. D. Cal. 1913); (1936) 22 VA. L. Rev. 465, 466.

93. MícLaughlin Land \& Livestock Co. v. Bank of America, 94 F. (2d) 491 (C. C. A. 9th, 1938).

94. Chicago Title \& Trust Company v. Forty-One Thirty-Six Bldg. Co., 302 U. S. 120 (1937), (1938) 51 Harv. L. Rev. 546, (1938) 22 Minn. L. REv. 721, (1938) 24 VA. L. REv. 322.

95. Whether suspended corporations may reorganize under Chapter $\mathrm{X}$ is speculative. It has been argued that whereas for jurisdiction in bankiruptcy only the undistributed assets of a corporation are necessary, for reorganization a live corporate entity is essential. See (1935) 48 HARv. L. REv. 676.

96. See, c.g., Weinstein, Corparations Amenable to Sction $77 B$ (1935) $83 \mathrm{U}_{\text {, or }}$ PA. L. Rev. 853; (1938) 24 VA. L. Rev. 322, 323. 
Revivor: The outstanding attribute of a suspended corporation is the possibility of revivor. Most suspension statutes provide for revivor or reinstatement of the corporation by the payment of back taxes and compliance with other penalties. ${ }^{97}$ They are divided as to whether the application for reinstatement must be within a fixed time. In interpreting the Texas statute requiring revivor within six months, the court, calling the statute one for the purpose of securing revenue, permitted revivor after the expiration of twenty-three years. ${ }^{98}$ More usual is the Missouri ruling which deems the right of revival abandoned after a suspension of five years. ${ }^{09}$ Once dissolution proceedings have been begun by the state following a period of suspension, the corporation has no right to be reinstated and may not by proceedings in mandamus compel the state to revive it. ${ }^{100}$ Before the institution of such proceedings and before the lapse of a reasonable time, the right to reinstatement may be regarded as absolute if the prescribed conditions are fulfilled. ${ }^{101}$

Upon fulfillment of the requisite conditions, the corporation is restored to its former status under the old charter. ${ }^{102}$ Its existence is no longer subject to collateral attack. ${ }^{103}$ Hence any method of revival that satisfies the state, or an appearance of compliance with the law, is conclusive upon the world. Only the state in quo zearranto proceedings may question the finality of the reinstatement.104 Under this doctrine anyone may pay the tax and secure the reinstatement of the corporation ${ }^{105}$ so long as the state does not object. Thus it has been held that a stockholder may bring about the revival in order to maintain suit in the corporation's behalf, even though the stock was obtained after suspension. ${ }^{106}$ And a minority of the directors may authorize a revival, with payment from the corporate funds, regardless of the fact that the charter requires acquiescence by a majority. ${ }^{107}$ Because it would be im-

97. For typical statutes see note 1, supra. For their application and interpretation, see Held v. Crosthwaite, 260 Fed. 613 (C. C. A. 2d, 1919) ; Rossi v. Claire, 186 Cal. 544, 199 Pac. 1042 (1921); Ruth v. Devany, 84 Colo. 476, 271 Pac. 623 (1928); Deschutes Co. v. Iara, 127 Ore 57, 270 Pac. 913 (1928).

98. Federal Crude Oil Co. v. Yount-Lee Oil Co., 122 Tex. 21, 52 S. W. (2d) 56 (1932), (1933) 11 TEx. L. REv. 250.

99. Estel v. Midgard Inv. Co., $46 \mathrm{~S}$. W. (2d) 193 (Afo. App. 1033) ; cf. Boyce v. Hinkle, 139 Wash. 164, 245 Pac. 927 (1926).

100. Metropolitan Building Corp. v. Ryan, 141 Kan. 521, 41 P. (2d) 1002 (1935).

101. But see Rossi v. Claire, 186 Cal. 544, 199 Pac. 1042 (1921) (the acerual of property rights to a stockholder after suspension will prevent revival).

102. Talcott Land Co. v. Hershiser, 1S4 Cal. 748, 195 Pac. 653 (1921); Shoen v. Lipkin, 105 Pa. Super. 127, 159 Atl. 198 (1932); Federal Crude Oil Co. v. Yount-Lee Oil Co., 122 Tex, 21, 52 S. W. (2d) 56 (1932).

103. McKee v. Standard Minerals Corp., is Del. Ch. 97, 156 Atl. 193 (1931) (a private person may not question the corporate reinstatement); Laird v. Pan-American Lumber Co., 237 S. W. 1047 (Mo. App. 1922) (nor may stodsholders).

104. McKee v. Standard Minerals Corp., 18 Del. Ch. 97, 156 Atl. 193 (1931).

105. See note 53 , stipra.

106. Southern Land Co. v. McKenna, 100 Cal. App. 152, 280 Pac. 14 (1929).

107. McKee v. Standard Minerals Corp., 18 Del. Ch. 97, 156 Atl. 193 (1931). 
possible to form a new corporation in this manner, the revived corporation is not, in the eyes of the state, a new or different organization. ${ }^{108}$ Hence, as a general rule, a suspended corporation does not lose its name. ${ }^{100}$ If, however, during suspension another corporation has adopted the same name or one so similar as to be deceiving or confusing, the revived corporation may not claim a right to the former name, but must assume a new one.110 An extremely slight change in the title so that it remains substantially like the old one, even though no corporation has assumed the former name, will not defeat revivor, and a corporation which applies for revivor with this defect may be reinstated as the identical corporation which existed prior to stuspension. ${ }^{111}$

A corporation which is reinstated may maintain suit on a cause of action arising before suspension. ${ }^{112}$ There are some indications that the statute of limitations will not run against a plaintiff corporation during the period of suspension, but this is certainly open to serious question and has not been definitely settled. ${ }^{113}$ Possibly it should be held to run against the corporation, but not against the person who by statute or judicial interpretation is unable to maintain suit against the corporation during the period of suspension. This would serve the intent of the statutes in penalizing the corporation, but would not militate against the rights of innocent parties.

When suit by a suspended corporation is dismissed because of statutory prohibition against the maintenance of an action during suspension, stit upon the same cause of action after reinstatement will not be prejudiced.14 This is consonant with the principle that suspension will not be construed in a manner to impair any action, defense, or right which might accrue upon revival. Similarly, upon reinstatement a corporation may be heard to appeal from a judgment taken before suspension. ${ }^{115}$ And, since the corporation is in a state of "suspended animation," suspension during a suit will not, in

108. Talcott Land Co. v. Hershiser, 184 Cal. 748, 195 Pac. 653 (1921); Pippin v. McMahon Bros., 33 Del. 42, 130 Atl. 37 (1925). For the logical difficulties encountered when a corporation treats suspension as forfeiture and reincorporates, see Turner $v$. Western Hydro-Electric Co., 241 Mich. 6. 216 N. W. 476 (1927).

109. Talcott Land Co. v. Hershiser, 184 Cal. 748, 195 Pac. 653 (1921).

110. Southern Land Co. v. McKenna, 100 Cal. App. 152, 280 Pac. 144 (1029). But the fact that another corporation has assumed the name of the suspended corporation will not defeat revivor.

111. Pippin v. McMrahon Bros.. 33 Del. 42, 130 Atl. 37 (1925).

112. Karnes v. Flint, 153 W'ash. 225, 279 Pac. 728 (1929).

113. The rulings on the subject have been by indirection. It was indicated in rinch v. Finch, 68 Cal. App. 72, 228 Pac. 553 (1924) that the statute would run as ustual. Sce also Comm'r of Int. Rev. v. Bryson. 79 F. (2d) 397 (C. C. A. 9th, 1935). But in Desechutes Co. v. Lara, 127 Ore. 57, 270 Pac. 913 (1928) the statutory period had evidently expired prior to the institution of the suit by the corporation. And in Clegg v. Roscoe Lumber Co., 161 S. W. 944 (Tex. Civ. App. 1913) the court held that suit by a sus pended corporation, even though void, would toll the statute.

114. Nedau v. United Petroleum Co., 251 Mich. 673, 232 N. W. 202 (1930).

115. San Leandro Canning Co. v. Perillo, 84 Cal. App. 627, 258 Pac. 666 (1927). 
the absence of statute, dismiss the action. ${ }^{110}$ The suit, rather, remains dormant, and upon reinstatement may be continued. In the absence of statutes voiding all acts of a corporation during suspension, the magic of reinstatement has been held to validate actions which occurred during the suspension period.117 This rule, plus an underlying estoppel, applies with full force to persons dealing with a suspended corporation in its corporate capacity, and a contract concluded under these conditions is properly enforceable by either party upon revivor.

\section{CoNCLUSION}

It has been implicit in this discussion that the problems involving suspended corporations will increase in number and complexity. As the state continues to cast about for methods of control more effective but less drastic and cumbersome than forfeiture, it is inevitable that new problems will be presented. Judicial indecision born of statutory indefiniteness obscures the underlying purpose of the enactments. Too often equities of a single situation or analogies from distantly related fields give a mistaken directive force to a hurriedly drawn statute. To assist the courts in understanding the legislature and to aid the legislature in achieving its desired control, it is suggested that statutes containing the following provisions might be enacted:

1. Absolute and automatic suspension of the right of a corporation to do business as a penalty for noncompliance with the specified requirements.

2. Continuation of the corporate entity for the purpose of defending suits. The corporation should be denied affirmative relief either in the way of a defense or in an independent action.

3. Liability of the organization as a de facto corporation for acts committed and contracts consummated during suspension.

4. Filing of bankruptcy petitions during suspension by any creditor or by the corporation itself.

5. Rights of revivor for a limited time. Revivor should restore the corporation to its former status and validate acts committed during suspension as well as restoring rights existing before suspension.

6. Forfeiture of the corporate charter without judicial proceedings by an entry on the records of the proper official if no revivor were attempted within the specified time.

7. Application of the regular corporate dissolution acts if such a forfeiture did occur.

116. Jarvis v. Chapman, 110 Fla. 17, 147 So. 860 (1933).

117. Held v. Crosthwaite, 260 Fed. 613 (C. C. A. 2d, 1919); Clegg v. Roscoe Lumber Co., 161 S. W. 944 (Tex. Civ. App. 1914). Where statutes provide that all acts of a corporation during suspension are void, reinstatement does not validate such acts. Van Iandingham v. United Tuna Packers, 189 Cal. 353, 203 Pac. 973 (1922) (contract invalid); Smith v. Lewis, $211 \mathrm{Cal}$ 294, 295 Pac. 37 (1930) (judgment roid); Ransome-Crummey Co. v. Superior Court, 188 Cal. 393, 205 Pac. 446 (1922) (revival is not retroactive). 